\title{
A new species of Ceraleurodius from the Amazon Basin (Aleyrodidae: Homoptera)
}

\author{
Norman D. Penny ( $\left.{ }^{*}\right)$
}

Jorge R. Arias (")

\begin{abstract}
A new species of Aleyrodidae, Ceraleurodius duckei $\mathrm{n} . \mathrm{sp}$. , is described and comparisons are made with its nearest relatives.
\end{abstract}

\section{INTRODUCTION}

In 1922 Hempel described the new genus Ceraleurodius and included in it two new species, $C$. nitidulis and C. splendidus. The same year, sometimes using the same material, Bondar described the same new genus with the name Radialeurodicus. There were two included species, $R$. assymetrus and $R$. cinereus. Radialeurodicus cinereus is an objective synonym of Ceraleurodius splendidus. In 1923, Bondar published his "Aleyrodideos do Brasil", where he retained the generic name Radialeurodius because Hempel's name Ceraleurodius was based on the type species $\mathrm{Ce}$ raleurodius splendidus, which Bondar considered a composite species. Bondar explained the material on which Hempel originally based the species description of $C$. splendidus was borrowed from Bondar, and Hempel had confused the nymphs of one species with adults of another. Bondar's revision (1923) included two new species of Radialeurodius, and he added three more species names in 1928 . Laing (1930) and Baker (1937) also contributed new names to the genus.

However, Costa Lima (1928) continued using the first published name, Ceraleurodius, and added two more new species. By 1940 Bondar himself had accepted the name Ceraleurodius, and shifted two species from the genus Quaintancius. Thus, with this new species, there are now 12 valid species names in the genus Ceraleurodius; Mound \& Halsey (1978) listing all but two of them as being from Brazil.

\section{Ceraleurodius duckei n. sp (Figs, 1-3)}

Description based on 1 male, in alcohol. Holotype male in Systematic Entomology Collections of INPA, Manaus.

Head:

Bluntly quadrangular in dorsal aspect. Vertex elevated above eyes, creamy with fuscous border, extending as thin strip behind compound eyes. Ocelli near compound eyes on occiput, clear with red border. Compound eyes large, red, strongly emarginate. Antennae consisting of short, fuscous scape; short pedicel, fuscous basally, abruptly changing to light yellow distally: flagellum of five long. thin, light yellow segments. Frons, clypeus and genae light fuscous. Rostrum short, reaching only to front pair of legs, light yellow changing to fuscous apically.

Thorax:

Pronotum collar-like, fuscous. Scutum of mesonotum consisting of anterio-lateral fuscous lobes and posterio-lateral, fuscous tegula. Medial lobes of mesoscutum heartshaped, fuscous, anterior lobe and hour-glassshaped, fuscous, posterior lobe. Sulcus between medial lobes of mesoscutum a light yellow, V-shaped line. Mesocutellum raised, triangular, light yellow with medial, longitudinal, brown band. Metanotum of two quadrate, depressed, light yellow sclerites. Meso- and metapleuron light fuscous.

Legs:

Basally grouped close together with large coxae. All legs with light fuscous coxae,

(*) - Instituto Nacional de Pesquisas da Amazônia, Manaus. 


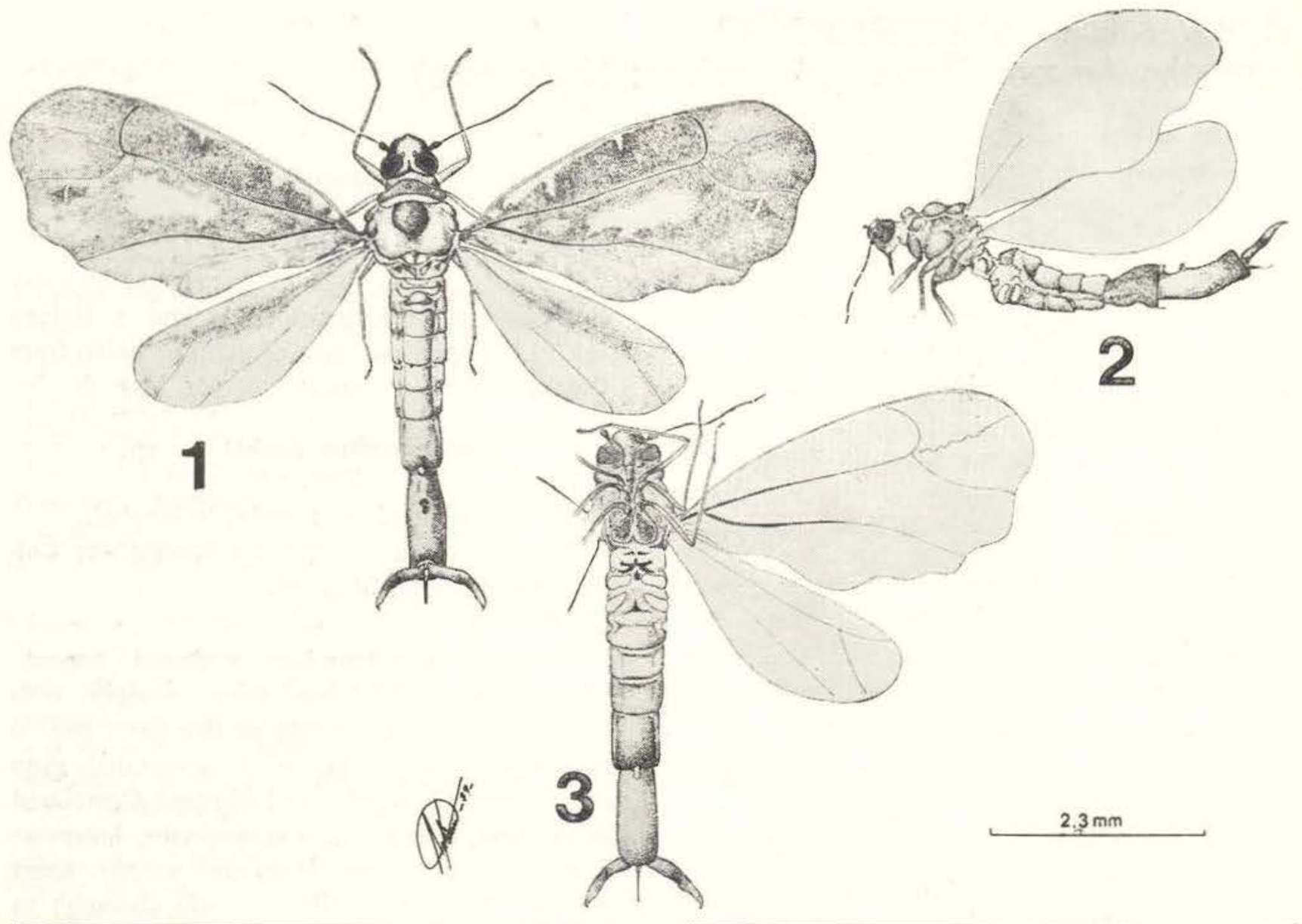

Fig. 1-3: 1) - Dorsal view of Ceraleurodius duckei $n . s p . ; 2)-$ Lateral view of Ceraleurodius duckei $n$. $s p . ;$ 3) - Ventral view of Ceraleurodius duckei $\mathrm{n}$. $\mathrm{sp}$.

trochanter and basal quarter of femur. Remainder of legs very light yelıow, almost white. Two tarsal segments with first segment about four times as long as second segment.

\section{Tegmen:}

Generally elongate with falcate sculpting three times along apical margin and three times on anal margin (Figs. 1,3). Ground color dark fuscous with golden spots basally along costal and anal margins, centrally between Radial sector (Rs) and Medius (M), and apically extending from behind termination of Rs to costal margins. Radius $(R)$ reaching costal margin about $2 / 3$ distance to apex, Rs unbranched, evenly curved from origin to apical margin. $M$ curved upward for short distance near mid-length. Cubitus $(\mathrm{Cu})$ indi- cated as clear, straight line. Subcosta (Sc) absent.

\section{Hindwing:}

Light fuscous. $\mathrm{R}$ almost reaching apical margin. $\mathrm{M}$ long and straight. $\mathrm{Cu}$ not distinguishable.

\section{Abdomen of Male:}

Seven abdominal segments, shading gradually from yellow anteriorly to dark brown posteriorly. First six terga divided into raised medial area and smaller, depressed lateral areas. Dividing lines between medial and lateral areas of terga darker fuscous, forming two longitudinal, dorsal stripes. Caudal apex of terga VI with a small raised knob, which 
when tergum VII is raised, fits into small depression at anterior margin of tergum VII. Sterna I and II with large lateral placs. Sternum III with small lateral plac. External male genitalia consisting of two, long, lateral lobes bright, orange, changing abruptly to black, then to pale yellow distally. Medial genital filament long, thin, dark fuscous.

Male Body Length (excluding genital lobes): $4.15 \mathrm{~mm}$.

Male Tegmen Length: $3.21-3.33 \mathrm{~mm}$.

Damage: The apical margins of both hindwings are missing.

Holotype male from BRAZIL: Amazonas, Reserva Ducke, 26 km NE of Manaus, 15-VII-1979, Jorge R. Arias and Norman D. Penny. Collected in light trap at $15 \mathrm{~m}$ height.

Female: Unknown.

Host Plants: Unknown.

Immature Stages: Unknown.

This species of Ceraleurodius is unique among described species of this genus in size, wing pattern and color pattern of the male genitalia. It shows no evidence of the white, wax-like covering for which most aleyrodids are recognized. Bondar has described this genus (under the name Radialeurodicus) as the most primitive of the family, after Udamoselis (which Mound and Halsey have listed as a nomina dubia).

Ceraleurodius duckei is named for Dr. Adolpho Ducke, early pioneer in Amazonian entomology and for whon INPA's Reserva Ducke is named.

We wish to thank $\mathrm{Sr}$. Artemio Coelho da Silva for the illustrations.

\section{SUMÁRIO}

Uma nova espécie de Aleyrodiciae, Ceraleurodius duckei n. sp., é descrita, a partir de um macho e comparada com outras espécies relacionadas.

\section{LITERATURE}

BAKER, J.M.

1937 - Notes on some Mexican Aleyrodids. An. Inst. Biol. Mexico, 8: 599-629.

BONDAR, G,

1922 - Insectos daninhos e moléstias do coqueiro (Cocos nucifera) no Brasil Imprensa Oficial do Estado da Bahia. Salvador. Bahia. $113 \mathrm{p}$.

1923 - Aleyrodideos do Brasil Imprensa Oficial do Estado da Bahia. Salvador, Bahia. 182 p.

1928 - Aleyrodideos do Brasil. II. Bol. Lab. Path. veg., Bahia. N. 5. $37 \mathrm{p}$.

1940 - Insetos nocivos e moléstias do coqueiro (Cocos nucifera) no Brasil. Imprensa Oficial do Estado da Bahia. Salvador, Bahia. $160 \mathrm{p}$.

COSTA LimA, A. DE

1928 - Contribuiçāo ao estudo dos aleyrodideos da subfamilia Aleurodicinae. Suppl. Mem. Inst. Oswaldo Cruz, Rio de Janeiro. (4): 128-140.

HEMPEL, A.

1922 - Algumas espécies novas de Hemipteros da familia Aleyrodidae. Not. Prelim. Rev. Mus. Paulista, 2 (1): 1-10.

LAING, $\mathrm{F}$,

1930 - Description of a new species of Aleyrodidae. Stettin. ent. Ztg., 91: 219-221.

MOUND, L.A. \& HALSEX, S.H.

1978 - Whitefly of the World: a Systematic Catalogue of the Aleyrodidae with Host Plant and Natural Enemy Data. London. Brit. Mus. Nat. Hist., 340 p.

(Aceito para publicaçăo em 22/01/80) 